\title{
Efficacy and Tolerability of Oral Iron Protein Succinylate in the Treatment of Iron Deficiency Anemia in Adults with Diverse Pathologies
}

\author{
Antonio Martinez-Frances \\ Haematology Department, University Hospital of Santa Lucia, Cartagena, Spain
}

Email address:

amartifran@gmail.com

\section{To cite this article:}

Antonio Martinez-Frances. Efficacy and Tolerability of Oral Iron Protein Succinylate in the Treatment of Iron Deficiency Anemia in Adults with Diverse Pathologies. American Journal of Internal Medicine. Vol. 9, No. 4, 2021, pp. 171-185. doi: 10.11648/j.ajim.20210904.13

Received: May 16, 2021; Accepted: June 7, 2021; Published: July 9, 2021

\begin{abstract}
An increasing number of prevalent conditions in the adult population associated with absolute or/and functional iron deficiencies (ID) may predispose to iron deficiency anemia (IDA). Oral iron formulations, especially ferrous salts, are generally regarded as the first line therapies for adult-onset ID and IDA according to several current guidelines. However, they have been frequently associated with gastrointestinal side effects, and with a subsequent high treatment discontinuation. Iron protein succinylate (IPS) is an iron complex containing $5 \%$ of ferric iron engulfed in a succinylated casein shell that precipitates in acid $\mathrm{pH}$ and becomes soluble at neutral to alkaline $\mathrm{pH}$, gradually releasing iron into the intestinal lumen, and, hence, overcoming the gastric and intestinal problems of the ferrous compounds, as well as improving intestinal iron absorption. Besides, IPS has shown to prevent the up regulation of the expression of hepcidin or to induce its expression at a smaller extent when compared with ferrous sulphate (FS). This narrative review addresses the efficacy and safety profiles of IPS for the treatment of ID and IDA in adult patients with a wide range of clinical conditions, such as preoperative and postoperative ID, elderly ID, Chronic Kidney Disease (CKD), Hypothyroidism, regular blood donors, and ID developed in young athletes. In conclusion, IPS compares favorably in efficacy and safety with other currently available oral iron preparations, showing a fast and steady improvement in hematologic parameters (that reflect a better iron absorption), and a lower incidence of adverse events.
\end{abstract}

Keywords: Iron Deficiency, Iron Deficiency Anemia, Adults, Iron Protein Succinylate, Oral Iron Treatment

\section{Introduction}

Iron deficiency anemia (IDA) is the most common cause of anemia worldwide [1]. It is estimated that more than 2 billion people worldwide are affected by iron deficiency (ID) [2], and it would contribute to $50 \%$ of all the diagnosed anemias [3]. The annual incidence rates of IDA range between 7.2 and 13.96 per 1000 person - years, with the highest estimations in Spain and Germany, among the developed countries [4].

There is an increasing number of prevalent conditions, associated with an altered iron metabolism, that predispose to ID and IDA in adults, reflecting either an absolute or a functional iron deficiency, or even the coexistence of both: 1) Increased iron requirements, as it happens in specific populations, like young fertile women, because of their heavy menstrual blood losses, and during pregnancies; 2) Decrease intestinal iron absorption, that is the consequence of several surgery interventions 3) Chronic blood loss, in conditions like gastrointestinal benign and malignant lesions, drug intake (salicylates, corticosteroids, NSAIDs), heavy menses, hematuria, and regular blood donors; and 4) Multiple mechanisms (frequently associated with inflammation), such as chronic kidney disease (CKD), chronic heart failure (CHF), inflammatory bowel disease (IBD), elderly people, thyroid dysfunction, and endurance athletes due to the hemolysis, blood loss, and often mild associated inflammation, etc $[5,6]$.

Oral iron treatment

Oral iron formulations are generally regarded as the first line treatment for ID and IDA conditions according to most guidelines [7]. However, the iron oxidation state in oral iron formulations seems to have a relevant role in the treatment efficacy and safety: several oral ferric compounds are associated with low bioavailability [8], while ferrous sulphate 
(among other ferrous oral preparations) is related with a high incidence of gastrointestinal adverse events [9].

Recently, several articles have related higher hepcidin response to oral iron treatment with a lower efficiency in the treatment $[10,11]$. Since hepcidin increases block iron absorption, authors have suggested that lower oral iron doses could be beneficial for the long-time treatment by achieving similar efficacy results than higher doses while reducing the amount of free iron in the gut -that could eventually induce gastrointestinal side-effects-.

Iron protein succinylate

Iron protein succinylate (IPS) is an iron complex containing $5 \%$ of iron in ferric form engulfed in a succinylated casein shell that has been used in the management of ID and IDA for over 30 years. This molecule has recently proved to be as effective as other ferrous iron therapies, such as ferrous sulphate, and to have a more favorable safety profile than these in gynecologic, pediatric and non-gynecological adult population [12].

Moreover, IPS has shown to either prevent the up regulation of the expression of hepcidin or to induce its expression at a smaller extent when compared with ferrous sulphate (FS) at the equivalent dosage of $200 \mathrm{mg}$ for both drugs (figure 2). This finding supports the beneficial effect of IPS enhancing iron absorption by avoiding the up regulation of the serum levels of hepcidin associated with iron intake [13].

Objective

This narrative review aims to address the efficacy and safety profiles of iron-protein succinylate (IPS) for the treatment of ID and IDA in adult patients with a wide range of clinical conditions (excluding gynecological and gastrointestinal etiology anemias, that are discussed in previous publications).

\section{Methods}

For the purpose of the present narrative review, seventeen studies have been selected and extracted from a previous literature search aimed at systematically reviewing the full evidence of IPS in diverse populations along 30 years (table 4 ), and whose methodology and results have been already published [12].

\section{Results}

IPS was investigated in 17 studies that enrolled adult patients with a wide range of medical conditions: six studies were conducted in adult general patients affected by IDA; one study in CKD anemic patients; one study in preoperative anemia due to menorrhagia, and three further trials in postoperative anemia; two studies in elderly population; one study in anemic patients due to hypothyroidism; one study in regular blood donors; and two studies in athletes with ID.

\subsection{General Adult Population}

Both absolute and functional iron deficiencies are quite prevalent in the adult general population setting, often preceding the development of IDA, and consequently impacting negatively on their physical capacity, work productivity, and cognitive function, importantly in older patients [14-16]. Other than the most frequently reported cause of IDA in adults, namely blood loss of gastrointestinal etiology, there are many pathologies and conditions associated with an imbalance between iron demand and supply in adults. Young menstruating women [17], blood donors [18-20], and endurance athletes [21-24] are regarded as healthy subjects at risk of developing IDA due to excessive and uncompensated blood losses and requirements. Additionally, many adult patients suffering from chronic diseases (like chronic kidney disease and chronic systolic heart failure) will develop ID as a result of combined multiple causes, such as decreased iron absorption, inflammation and increased blood loss [25-29]. Furthermore, elderly subjects comprise a very special adult subpopulation commonly affected by anemia of multifactorial etiology, that is associated with increased morbidity and mortality [5, 30, 31].

Most guidelines and expert reviews on the management of ID and IDA in a general adult setting recommend the early identification and individualized treatment of the underlying causes, and agree on the administration of iron supplementation to normalize hemoglobin concentrations and replenish iron stores, as well as to improve quality of life and reduce all related morbidity $[2,6,7,14,15,17,32,33]$. Iron therapy should be administered immediately, either for ID or IDA, especially in symptomatic subjects, being oral iron the first therapeutic choice for most patients, according to Guidelines [7, 14, 15, 17, 32].

Results from several studies evaluating oral IPS for the treatment of ID and IDA associated to different conditions and pathologies in adult populations are discussed hereunder.

Oral Iron Protein Succinylate (IPS) in General Adult Population with Sideropenic Anemia

Two similar randomized studies compared IPS with extracted ferritin for the treatment of IDA in patients form several etiologies. In both studies the dose of administered oral iron was $80 \mathrm{mg} /$ day, and the study follow-up was 30 days:

In the study conducted by Danisi et al [34] in 31 adult patients (mean age: 58 ) with IDA secondary to pulmonary diseases, both groups yielded a significant improvement in all the hematological parameters (RBC count, $\mathrm{Hb}$, and serum iron), at study completion versus baseline. However, ferritin was significantly increased only in the IPS study arm, reflecting a higher amount of stored iron. On the other hand, both drugs, IPS and extracted ferritin, demonstrated a considerable iron absorption (as tested with the combination of $\mathrm{Hb}$ iron and storage iron, with the Gordeuk formula) [35].

In the second study [36], 30 adult patients with IDA secondary to diverse etiologies (mean age: 68) were randomized to receive either IPS or extracted ferritin for an average treatment time of thirty days. Statistically significant differences in favor of IPS were observed in $\mathrm{Hb}, \mathrm{RBC}, \mathrm{MVC}, \mathrm{MCH}$, and MCHC. Furthermore, all the symptomatology due to IDA (Asthenia, Skin pallor, mucosa pallor, Fatigue) was improved in the IPS group, while only asthenia and fatigue showed improvements with 
extracted ferritin. Both drugs' tolerability was regarded excellent by study subjects. Therefore, IPS proved better clinical efficacy than extracted ferritin probably due to its better absorption, according to the study authors.

The above results were confirmed in a third study likewise comparing $80 \mathrm{mg}$ daily of IPS with extracted ferritin (dose equivalent to $80 \mathrm{mg}$ daily) in 20 patients diagnosed with IDA of several etiologies for a follow-up of 30 days [37]. IPS achieved a significantly higher increase in $\mathrm{Hb}$ values than that obtained with ferritin. Absorption of IPS was deemed significantly higher with IPS than with extracted ferritin $(\mathrm{p}=0.004)$ : $9.84 \%( \pm 3.64)$ and 5.38\% $( \pm 1.93)$ respectively.

The absorption of iron from three different preparations containing either extracted ferritin ( $80 \mathrm{mg}$ of $\mathrm{Fe} 3+$ ), ferrous sulphate (FS) (105 mg of $\mathrm{Fe} 2+$ ), or IPS ( $80 \mathrm{mg}$ of $\mathrm{Fe} 3+$ ), was assessed in a further trial in adults diagnosed with IDA of different etiology, by means of a loading curve and the method proposed by Ekenved [38]. The study consisted of 2 periods:

In the first part of the study, the kinetics of the respective three treatments' absorption was evaluated in the same 10 patients, after the random administration of a single dose of the three drugs under fasting conditions, each separated by a wash-out period of 4 days on average. Blood samples were extracted at $0.5,1,2,3,4,5$ and 6 hours on each day. Results showed a comparatively faster increase in SI concentration levels, and higher and more sustained IPS concentration levels along the whole assessment period [39].

The second part of the trial was performed in 30 outpatients with moderate IDA, randomized to receive either FS (105 mg of $\mathrm{Fe} 2+$ ), extracted ferritin ( $80 \mathrm{mg}$ of $\mathrm{Fe} 3+$ ) or IPS (80 $\mathrm{mg}$ of $\mathrm{Fe} 3+$ ), for 28 days. The three preparations showed significant increases in the following hematologic parameters: $\mathrm{Hb}$, serum iron, total iron binding capacity (TIBC), and transferrin saturation [39].

Percentual iron absorption from the three drugs was calculated based on the serum iron increase observed during treatment and yielded a slightly higher absorption result for IPS when compared to the other molecules: $6.125 \%$ for IPS, $5.90 \%$ for FS, and $5.54 \%$ for extracted ferritin [39].

In another two months randomized single-blind study, 40 adult patients of both sexes, with IDA secondary to diverse etiologies (mean age: 41 ) were assigned to IPS $80 \mathrm{mg}(20$ patients) or iron gluconate complex (IGC) $125 \mathrm{mg}$ (20 patients). At two months, both drugs significantly increased the following parameters: Hct, Hb, serum iron, serum ferritin, RBC, and MCV. However, despite the lower dose used with IPS, changes in some laboratory parameters (serum iron, serum ferritin, TIBC and MCV) were observed earlier with IPS. Furthermore, greater improvements in favor of IPS were observed in the following variables: $\mathrm{Hb}$, Hct, serum ferritin and reticulocyte count [40].

Differences in tolerability between the two study arms were observed: while only 2 IPS-treated patients informed of mild and transient adverse events, 10 of the 20 patients in the IGC group reported side effects, with one patient requiring treatment and two further patients discontinuing the study drug due to severe adverse events, namely nausea, vomiting and heartburn [40].

Another study performed in general adult population suffering from IDA of diverse etiologies compared IPS at two different daily dosages (80 $\mathrm{mg}$ and $120 \mathrm{mg}$ ) with extended release (ER) iron sulphate $(105 \mathrm{mg})$. Fifty-four patients (mean age, 57) were followed-up for 60 days. At study completion, $\mathrm{Hb}$ increased $45 \%, 34 \%$ and $29 \%$ in the IPS $120 \mathrm{mg}$, the IPS $80 \mathrm{mg}$, and the ER FS groups, respectively (Figure 1); however, no statistical significance between-groups was observed. Additionally, IPS at both tested doses showed a significantly better tolerability profile than ER iron sulphate, with significantly fewer reported adverse events $(p<0.001)$. Of note, four patients in the ER FS group discontinued the study because of tolerability complaints, while no patients in both IPS groups did so, due to safety reasons [41].

Hemoglobin variations in adults with IDA

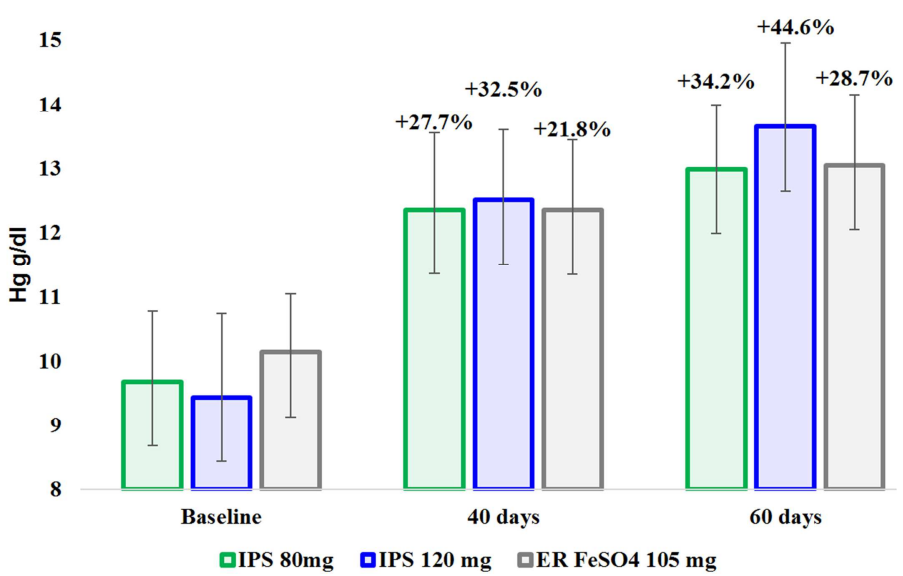

Figure 1. Haemoglobin (Mean +SD., g/dl) variations and increases (\%) from baseline in adults with IDA (adapted from Pogliani, 1990).

*40 days / 60 days vs baseline: $\mathrm{p}<0.01$

Between treatments: non-significant

IPS: Iron Protein Succinylate (80mg: $n=22 ; 120 \mathrm{mg}$ : $n=19$ )

$\mathrm{ER} \mathrm{FeSO}_{4}$ : Ferogradumet $(\mathrm{n}=13)$ 
Finally, the above shown efficacy and tolerability results were confirmed in a large randomized, double-blind, double-dummy, two-month multicenter clinical trial, that compared 120mg Fe3+/day IPS with $105 \mathrm{mg} \mathrm{Fe} 3+$ /day of extended release ferrous sulphate (ER FS) in a sample of 1,095 patients, with either ID or IDA, representative of the adult general anemic population [42]. After the study completion, at 60 days, values of $\mathrm{Hb}$, Hct, ferritin, and total body iron ( $\mathrm{Hb}$ iron and storage iron) were greater in the IPS group, denoting a more progressive and steady therapeutic effect. In addition, at study end there was a significant clinical improvement in the IPS group versus the ER FS group, in some IDA symptoms like asthenia, fatigue, and skin and mucosal paleness.

Regarding general tolerability, IPS treated patients reported a smaller number of adverse events (AEs), with a significantly shorter duration, and with a later onset. Furthermore, GI side effects were more frequently reported in the ER FS study arm [42].

\subsection{Chronic Kidney Disease}

Iron deficiency (ID) is a leading cause of anemia in chronic kidney disease (CKD) patients. ID may be due to an absolute (reduced iron stores) or functional (inefficient use of iron stores) iron deficiency [14].

The main international Guidelines (KDIGO, and NICE) recommend starting with oral iron treatment to correct the ID in non-dialysis-dependent CKD (NDD-CKD) patients (stages 1-5), as long as they are not on erythropoiesis-stimulating agents (ESA) therapy, they tolerate oral iron, and reach $\mathrm{Hb}$ targets within 3 months [43, 44].

Oral iron Protein Succinylate (IPS) in ID or IDA Patients with Chronic Kidney Disease

A randomized, double-blind, placebo-controlled, two-month clinical trial was conducted to evaluate the biological safety and subjective tolerability (with a special focus on GI Symptoms) of IPS (120 mg/day) in 30 patients with either ND-CKD $(n=14)$ or CKD on hemodialysis $(n=16)$ who had developed ID [45]. Secondarily, hematological parameters were monitored to assess the clinical efficacy of the study drugs. Fourteen patients were randomly assigned to IPS and sixteen to placebo.

At 30 days, most of the hematologic parameters significantly improved in the IPS arm compared to the placebo treated patients, in both the non-dialysis and hemodialysis groups. $\mathrm{Hb}$ concentrations steadily raised, while slightly decreased in the placebo-treated groups. Interestingly, there were differences observed between both groups (dialyzed versus non-dialyzed) in the final values of some parameters, like $\mathrm{MCH}, \mathrm{MCHC}$, TIBC, and serum iron concentration, although, according to the publication authors, these findings might not translate into a clinical significance.

According to the overall evaluation of the authors, the tolerability profile of the two treatments under study (IPS and placebo) was comparable.

In conclusion, data from this study suggested that IPS could be a safe and efficacious alternative treatment for anemia in CKD patients.

\subsection{Preoperative Anemia Management}

Preoperative IDA affects to approximately $40 \%$ of patients undergoing major surgery and it is regarded as an independent risk factor for perioperative blood transfusion, morbidity, and mortality. Preoperative IDA has an absolute or functional origin $[26,46]$. Guidelines on preoperative management of anemic patients recommend iron therapy for surgical patients before and after surgery [47]. Oral iron preparations are still considered first-line treatment, as they are effective, safe, and cheap [48].

Oral Iron Protein Succinylate (IPS) in Preoperative ID or IDA Management

Preoperative management of anemia was studied with IPS in a very short study: seventy-six IDA patients with menorrhagia were allocated to intravenous (i.v.) iron sucrose $(n=39)$ or 80 mg daily of oral IPS $(n=37), 3$ weeks before a surgical intervention, in an open-label randomized trial which objective was to evaluate the efficacy and safety of both treatments in the correction of the preoperative anemia due to menorrhagia [49]. At study completion, although IPS achieved improvements in the studied hematological parameters, the i.v. group showed statistically higher increases in $\mathrm{Hb}$, serum ferritin and MCV than the oral group. Tolerability for iron sucrose and IPS was reported as good by both group patients.

It must be said that, despite a faster correction of the hematologic parameters might be expected with the i.v. treatment, a premature cessation of the oral iron arm, with a subsequent reduction in surgical procedures, and the short study duration ( 3 weeks) have been regarded as important methodologic limitations and sources of bias by the study authors [49].

\subsection{Postoperative Anemia Management}

A recently published consensus statement on the management of postoperative anemia after major surgical procedures has addressed the epidemiology, pathophysiology, diagnosis, and management of anemia and iron deficiency in the postsurgical period [50]. This consensus document states that "Iron supplementation should be considered in patients with iron deficiency or significant reduction in postoperative hemoglobin, starting early in the postoperative recovery phase where there are no major complications". Notwithstanding, according to the panel of experts, oral iron supplements should be well absorbed and tolerated, with few gastrointestinal side-effects, and ideally their intestinal absorption should not be inhibited by the increased hepcidin synthesis and release stimulated by the inflammatory response [50].

Oral iron Protein Succinylate (IPS) in Postoperative ID or IDA Management

IPS has shown to be effective and safe in correcting the IDA following surgical interventions. Three publications assessed the efficacy and safety profiles of IPS in adult subjects who developed IDA following surgery interventions: 
A randomized single-blind clinical trial compared the efficacy and safety of $80 \mathrm{mg}$ of $\mathrm{Fe} 3+/$ day of IPS and $125 \mathrm{mg}$ of $\mathrm{Fe} 3+$ /day of iron gluconate for one month in 30 patients with ID due to GI pathology following medical or surgical intervention for treating the anemia cause. IPS proved to be more efficacious in ameliorating the clinical symptoms -even though it was administered at a lower dose of iron treatment-. No adverse events were reported in neither of the two study groups [51].

A second study prospectively assessed 18 patients who underwent different types of surgical interventions that caused IDA, from a cohort of 80 patients. Following 30 days of treatment with IPS ( $80 \mathrm{mg}$ of iron per day), while all the evaluated hematological parameter significantly improved, the increases in serum ferritin and serum iron concentrations were notably marked, which reflects the good iron absorption profile of IPS. Treatment tolerability was optimal, with only $7.5 \%$ of the entire study population reporting adverse events [52].

Lastly, a third study randomized 40 patients suffering from post-surgical iron deficiency to $40 \mathrm{mg}$ of $\mathrm{Fe} 3+$ daily of either IPS or a control group, consisting of an iron protein derived from saccharomyces cerevisiae cultures in the presence of iron, and they were followed-up for 30 days. At study completion, both groups improved all the hematological parameters, and the reported tolerability was good for all the study patients [53].

Overall, it can be said that the efficacy and tolerability profiles of IPS are as good as or even better than the comparative controls in the population of patients who underwent surgery.

\subsection{Elderly}

Iron deficiency (ID) and iron deficiency anemia (IDA) are relatively common in older people, being highly prevalent in people of 65 years and older, and accounting for around 30\% of all the diagnosed anemias in the elderly in Western countries [54, 55]. Anemia in this population is associated with fatigue, functional capacity and cognitive impairments, increased hospitalization, and mortality [5, 31, 46].

The underlying etiology of IDA in the elderly seems to be multifactorial, encompassing an inadequate dietary intake, an impaired absorption, a delayed gastric emptying, and an excessive iron loss of different causes. Either functional or absolute IDA is quite frequent in older people [5, 56, 57].

Guidelines on the diagnosis and treatment of ID and IDA recommend oral iron supplementation as the first line treatment in adults, including elderly patients, unless the oral therapy is either unsuccessful or the patient cannot tolerate it [7]. Nevertheless, there is scarce evidence supporting the most convenient pharmacological approach to treat ID and IDA in the elderly population, and a lack of response to treatment in older adults has not been defined yet [5].

Oral iron Protein Succinylate (IPS) in ID or IDA Elderly Patients

A single-cohort prospective study was carried out to evaluate the effect of IPS ( $80 \mathrm{mg}$ daily) on hematological parameters (including serum iron, $\mathrm{RBC}$ count, $\mathrm{Hb}, \mathrm{Hct}, \mathrm{MCV}$, $\mathrm{MCH}$. MCHC, TIBC, serum ferritin and TSAT) and on symptomatology in a population of 81 institutionalized elderly patients with iron deficiency, for a treatment period ranging between 3 and 6 months, and a subsequent follow-up period up to 12 months. The study results were contrasted with a matching control group of healthy subjects $(n=81)$. Clinical and hematologic parameters significantly improved versus baseline values in the study group, whereas an opposite trend was observed in the control group. In addition, the good safety and tolerability profile of IPS in this elderly population was confirmed by the low adverse events rate reported and by the patients and investigators assessments [58].

Similar results in an elderly subpopulation of 20 patients with IDA treated with IPS for three months had been previously reported [52].

Furthermore, the above commented findings were later confirmed in a large randomized 2-month clinical trial, with a subpopulation of elderly patients (age $>65$ years) with either ID or IDA, in which 73 patients treated with $120 \mathrm{mg}$ daily of IPS compared with 62 treated with $105 \mathrm{mg}$ daily of extended release (ER) FS. [42]. As previously commented, earlier and statistically significant improvements were observed in the IPS treated subgroup compared with the ER FS treated subpopulation in the following hematologic parameters: $\mathrm{Hb}$, Hct, ferritin and MCHC. As the authors point out, these findings presumably indicate a greater and faster increase in $\mathrm{Hb}$ iron, storage iron and total iron in the IPS treated patients' sample. Moreover, the reported general tolerability was significantly more favorable with IPS in terms of a smaller number of adverse events, later onset times, and shorter adverse event durations. Of note, in this elderly subgroup the efficacy and the tolerability of the tested medications resulted fully comparable to those observed in the other patients' subpopulations.

\subsection{Hypothyroidism}

Anemia and ID are frequently associated with thyroid dysfunction, particularly hypothyroidism. The etiopathogenesis of anemia in hypothyroidism seems to be multifactorial, and related to several conditions, such as decreased erythropoietin production, nutrient deficiency (including iron), and depressed bone marrow stimulation [59-61].

Oral iron Protein Succinylate (IPS) in ID or IDA Patients with Hypothyroidism

A randomized clinical trial assessed IPS and LT4 in the treatment of manifested sideropenic anemia (MSA) and thyroid dysfunction associated to $\mathrm{SH}$ [62].

The study was carried out in 33 adult women diagnosed with $\mathrm{SH}$ and MSA who were randomly assigned to three groups of 11 patients each (LT4 alone; $80 \mathrm{mg}$ daily of IPS alone; or $80 \mathrm{mg}$ daily of IPS + LT4), and were followed-up for 12 weeks.

At study completion, the group that received the combination of both LT4 and IPS achieved statistically significant better results when compared to the group that received LT4 alone (Table 1). Furthermore, this group recorded the greatest alleviation of symptoms like fatigue, dizziness, and general performance impairment, compared to the other groups. 
Table 1. Comparisons of serum concentrations of hemoglobin (Hb) and hematocrit (Ht), in 33 women with subclinical hypothyroidism and manifest sideropenic anemia (adapted from Duntas, 2000).

\begin{tabular}{lcll}
\hline Parameters & Group I & Group II & Group III \\
\hline $\begin{array}{l}\text { Before Treatment } \\
\text { Hb (nr: } 12-16 \mathrm{~g} / \mathrm{dl})\end{array}$ & $11.4 \pm 1.1$ & $11 \pm 0.8$ & $11.2 \pm 1$ \\
Hct (nr: $37 \%-47 \%)$ & $35.8 \pm 2.8$ & $35.5 \pm 3.1$ & $35.7 \pm 2.8$ \\
After Treatment & & & \\
Hb (nr: $12-16 \mathrm{~g} / \mathrm{dl})$ & $11.9 \pm 1.1$ & $12.7 \pm 1.2$ & $13.1 \pm 1.5^{*}$ \\
Hct (nr: $37 \%-47 \%)$ & $36.7 \pm 3.1$ & $37.8 \pm 3.5$ & $38.3 \pm 3.9$ \\
\hline
\end{tabular}

Patients were randomized into three groups of 11 patients each. Group I, received $\mathrm{LT}_{4}-100 \mu \mathrm{g}$ daily. Group II received I-PSL $80 \mathrm{mg} \mathrm{Fe}{ }^{+++}$, and Group III received I-PSL $80 \mathrm{mg} \mathrm{Fe}{ }^{+++}$and $\mathrm{LT}_{4}-100 \mu \mathrm{g}$ daily. $\mathrm{Nr}=$ normal range. $\mathrm{Hb}$ : Hemoglobin; Hct: Hematocrit

$* \mathrm{p}<0.05$ compared to Group I.

These results suggest a synergistic effect of iron supplementation and LT4 treatment. In addition, the three groups reported a good tolerability profile, since none of the study patients claimed any side effects [62].

\subsection{Regular Blood Donors}

Iron deficiency is highly prevalent among blood donors [63], with up to $65 \%$ of regular donors being iron deficient. Unfortunately, this population with a higher risk of induced ID has been rather frequently ignored [19]. Moreover, ID in blood donors has been associated with a series of complications, such as fatigue, decreased physical capacity, restless legs syndrome, pica, and several cognitive and psychological functions impairment [20].

Many studies have assessed the effect of iron supplementation in improving iron status in blood donors with ID. Daily Iron supplements with ferrous salts have shown to reduce the risk of iron deficiency in frequent blood donors and to recover hemoglobin and iron stores from blood donation $[18,19]$. However, this effect may take weeks to months, and treatment adherence may be reduced due to the frequent GI side effects associated to the ferrous salts intake [19, 64].

Oral iron Protein Succinylate (IPS) in ID or IDA Blood Donors

IPS ( $80 \mathrm{mg}$ daily) was compared in a randomized controlled trial with 105 daily $\mathrm{mg}$ of ferrous sulphate (FS) for the treatment of ID in a sample of 40 blood donors with low levels of stored iron, in a 30-day period of time [65]. Some hematologic parameters were evaluated. In addition, Iron absorption was calculated by means of the Gordeuk equation [35], and the safety profile and tolerability of both drugs were assessed.

At study end, a greater iron absorption was induced with IPS $(18,7 \%)$ compared with FS (6.4\%). Unlike FS, IPS significantly increased the serum iron concentration and hematocrit along with the amount of stored iron, evaluated as serum ferritin, at the end of the study (Table 2). On the other hand, both study groups reported good tolerability results.

In conclusion, IPS showed in this trial an overall better clinical profile compared with FS in the treatment of ID in the blood donor population.

Table 2. The effect of iron protein succinylate on the hematological parameters measured. Values shown are means $\pm S D$ ( $n=40)$ (adapted from Landucci, 1987).

\begin{tabular}{|c|c|c|c|}
\hline Parameters & Baseline & End of treatment ( 30 days) & $P$ value* \\
\hline \multicolumn{4}{|c|}{ Red blood cell count $/ \mathrm{RBC})\left(\times 10^{-3} / \mathrm{mm}^{3}\right)$} \\
\hline IPS (80mg/day) & $4349 \pm 274$ & $4404 \pm 201$ & 0.18 \\
\hline $\mathrm{FeSO}_{4}(105 \mathrm{mg} /$ day $)$ & $4358 \pm 432$ & $4347 \pm 268$ & 0.84 \\
\hline \multicolumn{4}{|c|}{ Hemoglobin $(\mathrm{g} / 100 \mathrm{ml})$} \\
\hline IPS (80mg/day) & $13.10 \pm 0.77$ & $13.26 \pm 0.59$ & 0.17 \\
\hline $\mathrm{FeSO}_{4}(105 \mathrm{mg} /$ day $)$ & $13.33 \pm 1.22$ & $13.37 \pm 0.85$ & 0.79 \\
\hline \multicolumn{4}{|l|}{ Hematocrit (\%) } \\
\hline IPS (80mg/day) & $39.4 \pm 2.3$ & $40.5 \pm 1.5$ & 0.012 \\
\hline $\mathrm{FeSO}_{4}(105 \mathrm{mg} /$ day $)$ & $40.2 \pm 3.3$ & $40.5 \pm 2.4$ & 0.45 \\
\hline \multicolumn{4}{|c|}{ Mean corpuscular volume $\left(\mu \mathrm{m}^{3} /\right.$ cell $)$} \\
\hline IPS (80mg/day) & $91.3 \pm 4.8$ & $92.6 \pm 3.7$ & 0.055 \\
\hline $\mathrm{FeSO}_{4}(105 \mathrm{mg} /$ day $)$ & $92.3 \pm 4.3$ & $93.6 \pm 3.0$ & 0.057 \\
\hline \multicolumn{4}{|c|}{ Mean corpuscular hemoglobin (pg/RBC) } \\
\hline IPS (80mg/day) & $30.20 \pm 1.6$ & $30.15 \pm 1.5$ & 0.85 \\
\hline $\mathrm{FeSO}_{4}(105 \mathrm{mg} /$ day $)$ & $30.49 \pm 1.7$ & $30.81 \pm 1.4$ & 0.15 \\
\hline \multicolumn{4}{|c|}{ Mean corpuscular hemoglobin concentration $(\mathrm{g} / \mathrm{ml})$} \\
\hline IPS (80mg/day) & $33.04 \pm 0.58$ & $32.59 \pm 1.05$ & 0.088 \\
\hline $\mathrm{FeSO}_{4}(105 \mathrm{mg} /$ day $)$ & $33.01 \pm 0.85$ & $32.83 \pm 1.04$ & 0.45 \\
\hline \multicolumn{4}{|c|}{ Serum iron $(\mu \mathrm{g} / 100 \mathrm{ml})$} \\
\hline IPS (80mg/day) & $58.50 \pm 24.0$ & $81.15 \pm 24.6$ & $<0.001$ \\
\hline $\mathrm{FeSO}_{4}(105 \mathrm{mg} /$ day $)$ & $66.50 \pm 27.6$ & $75.60 \pm 28.3$ & 0.17 \\
\hline \multicolumn{4}{|c|}{ Serum transferrin $(\mathrm{mg} / 100 \mathrm{ml})$} \\
\hline IPS (80mg/day) & $359.2 \pm 48.1$ & $347.0 \pm 44.6$ & 0.11 \\
\hline $\mathrm{FeSO}_{4}(105 \mathrm{mg} /$ day $)$ & $349.0 \pm 37.5$ & $352.7 \pm 47.5$ & 0.59 \\
\hline \multicolumn{4}{|l|}{ Serum ferritin (ng/ml) } \\
\hline IPS (80mg/day) & $22.15 \pm 14.4$ & $47.30 \pm 27.4$ & $<0.001$ \\
\hline $\mathrm{FeSO}_{4}(105 \mathrm{mg} /$ day $)$ & $26.35 \pm 23.5$ & $41.85 \pm 30.4$ & 0.006 \\
\hline
\end{tabular}

\footnotetext{
* Using a paired Student t-test; $P$ values statistically significant if $<0.05$.
} 


\subsection{Athletes}

Athlete populations, especially females (due to the increased iron demand to account for menses) and endurance athletes, are commonly diagnosed with iron deficiency. Athletes, suffering of ID, usually complain of fatigue, drowsiness, and mood changes. In cases of severe ID, the athlete's work capacity may be also compromised. In the end, all these symptoms have a negative impact on the athlete's ability to compete [24]. Therefore, maintaining a positive iron balance is critical for athletes to avoid the undesirable effects of ID and IDA [21, 22].

Iron supplementation is recommended when ID and IDA are suspected. Both oral iron supplementation and intravenous (i.v.) injections are effective treatments for IDA. It has been shown that iron supplementation increases serum ferritin in athletes [66]; while a recent meta-analysis has confirmed that iron treatments are effective for improving iron status and the aerobic capacity of iron [66].

The oral route for administering iron supplementations is the preferred and the most commonly recommended one, except for severe IDA cases, or where there is a time-critical need; for those subjects, iron injections may be more appropriate [22].

Oral iron Protein Succinylate (IPS) in ID or IDA Athletes

Two studies evaluated the effect of IPS in athletes:

The first one was conducted in a group of young female athletes who were treated with 40 to $80 \mathrm{mg}$ daily of IPS for 2 months and was compared with a control group of non-athlete women of the same age, also treated with the same range of doses of IPS and for the same period of time [67]. At baseline the RBC count, $\mathrm{Hb}$, and serum iron were significantly lower in the athletes' group. Conversely, females from the control group presented normal levels hematologic parameters.

After two months of IPS treatment, the athletes' group significantly improved $\mathrm{Hb}$ and serum iron versus baseline, with levels of both parameters within the physiological range. $\mathrm{RBC}$ count did not improve at study completion in neither of the study groups, since baseline levels were regarded as normal values (Table 3) [67].

A second study, performed in elite male cyclists, evaluated the effect of $80 \mathrm{mg} /$ day of oral iron supplementation on the hematological profile; muscle damage intracellular enzymes (CK, LDH, Mb) and cortisol levels were also evaluated. The study was conducted for 4 weeks during the Spanish big Cycling Tour: Vuelta Ciclista a España [68].

Results from this study confirmed that an oral supplementation with $80 \mathrm{mg} /$ day of IPS was enough to prevent a decline in hematological parameters (ferritin, $\mathrm{Hb}$ and Hct) and to reduce the accumulated stress in response to exercise intensity (as measured with serum cortisol levels) in elite sportsmen. Additionally, it was observed that hematological parameters were associated with muscle damage biomarkers [68].

In conclusion, IPS is an effective treatment for improving the iron status and for maintaining optimal levels of recovery in elite sportsmen.

Table 3. Differences in the hematological parameters between the control group and the group of sportswomen in the three analyses (adapted from Trojachanec).

\begin{tabular}{|c|c|c|c|c|c|c|c|c|c|}
\hline \multirow{2}{*}{ Test } & \multicolumn{3}{|c|}{ Erythrocytes $\left(1 \times 10^{9} / \mathrm{I}\right)$} & \multicolumn{3}{|c|}{ Haemoglobin (g/dl) } & \multicolumn{3}{|l|}{$\mathrm{Se} \mathrm{Fe} \mathrm{(mmol/l)}$} \\
\hline & Control group & Sports women & p & Control group & Sports women & p & Control group & Sports women & p \\
\hline Baseline (I) & $4.6 \pm 0.23$ & $4.3 \pm 0.11$ & $\mathrm{p}<0.05$ & $12.04 \pm 1.7$ & $10.98 \pm 2.1$ & n.s. & $12.47 \pm 0.4$ & $9.52 \pm 0.2$ & $\mathrm{p}<0.05$ \\
\hline One month (II) & $4.58 \pm 0.30$ & $4.45 \pm 0.26$ & n.s. & $11.86 \pm 2.2$ & $12.40 \pm 1.8$ & n.s. & $12.34 \pm 0.5$ & $13.04 \pm 0.4$ & $\mathrm{p}<0.05$ \\
\hline Two months (III) & $4.54 \pm 0.17$ & $4.40 \pm 0.27$ & n.s. & $13.64 \pm 2.1$ & $12.36 \pm 2.0$ & n.s. & $12.27 \pm 0.8$ & $14.09 \pm 0.7$ & $\mathrm{p}<0.05$ \\
\hline s.s I /II & n.s. & $\mathrm{p}<0.05$ & & n.s. & $\mathrm{p}<0.05$ & & n.s. & $\mathrm{p}<0.05$ & \\
\hline s.s I/III & n.s. & n.s. & & $\mathrm{p}<0.05$ & $\mathrm{p}<0.05$ & & n.s. & $\mathrm{p}<0.05$ & \\
\hline s.s II /III & n.s. & n.s. & & $\mathrm{p}<0.05$ & n.s. & & n.s. & $\mathrm{p}<0.05$ & \\
\hline
\end{tabular}

Se Fe: Serum Ferritin

\section{Discussion}

Iron deficiency, with or without anemia, and whether due to impaired iron absorption, abnormal iron losses, or increased iron request, is a highly prevalent consequence of multiple adult pathological conditions in developed countries $[1,14,15]$.

Oral iron therapies, especially ferrous salts, because of their theoretically better absorption and higher bioavailability compared with ferric iron salts, remain the gold standard [6, 14] and are still considered the first-line approach for treating adult onset IDA by most of the international guidelines [7]. However, oral ferrous salts, like ferrous sulphate (FS), have been frequently associated with GI side effects, and in consequence that has been the reason for the observed high treatment discontinuation [9]. Moreover, some oral ferrous supplements can even exacerbate GI symptoms in patients with pre-existing GI inflammation [69, 70]. In addition, FS has been found to induce hepcidin levels increase, thus limiting iron absorption [10].

Iron protein succinylate (IPS), an iron complex containing ferric iron engulfed in an electronegative protein carrier (a succinylated casein shell), that precipitates in an acid $\mathrm{pH}$ environment and becomes soluble at neutral to alkaline $\mathrm{pH}$ levels, was precisely developed to overcome the gastric and intestinal problems of the ferrous compounds, as well as the low iron absorption of the ferric iron preparations [71, 72]. IPS, by keeping iron bonded to its protein contents at low $\mathrm{pH}$ values, and by gradually releasing iron into the intestinal lumen, has demonstrated to protect the gastrointestinal mucosa from eventual damage, as well as ensuring an optimal and improved intestinal iron absorption [73, 74]. Besides, in a basic research study under publication, IPS kept 
hepcidin levels similar to baseline values after three days of treatment, while FS increased them, confirming the neutral effect of IPS on serum hepcidin levels, unlike FS (Figure 2).

The present narrative review has been focused on the action of IPS on ID and IDA in several adult pathological conditions, except for gastrointestinal diseases and pregnant women, that have been the objective of two other narrative reviews published elsewhere.

In all the included clinical trials adult patients with ID or IDA from different causes were enrolled, IPS, compared with the standard iron therapies, seemed to induce a fast and steady normalization of hematologic parameters (specially, $\mathrm{Hb}$, ferritin and serum iron concentration), indicating an optimal pharmacological effect on both iron absorption and iron stores replenishment. Furthermore, a consistent and parallel IDA clinical symptomatology improvement was observed across all the reviewed trials performed in general adult populations [37, 39-42, 74, 75].

IPS was tested in a sample of patients with chronic kidney disease with different renal insufficiency stages (either non-dialysis or hemodialysis). At study end, $\mathrm{Hb}$ and serum iron concentration had significantly improved in the IPS treated group of patients, confirming that IPS is an effective treatment for patients with chronic inflammatory diseases who have developed ID or IDA, and iron absorption was not impaired in those patients [45]. Although it is known that increased serum hepcidin concentrations in chronic inflammatory conditions may induce functional iron-deficiency anemia $[25,26,76]$, and hepcidin levels were not assessed in this trial, we might expect a neutral effect of IPS on hepcidin in chronic conditions, unlike the ferrous salts, according to the results observed in the above-mentioned preclinical study (figure 1). Furthermore, according to the current Guidelines recommendations, IPS might show clear efficacy and safety advantages for the CKD not on dialysis population, compared with other available oral iron treatments.

Interestingly, a further clinical trial evaluating the effect of IPS in IDA from other chronic inflammatory disease, chronic heart failure, is currently being conducted (https://www.clinicaltrials.gov/ct2/show/NCT03344523).

IPS has been investigated in clinical trials evaluating its effect on both preoperative and postoperative anemia. In the study carried out in anemic patients due to menorrhagia who underwent surgical treatment, IPS significantly improved hematologic parameters although at a lesser extent than with the comparator, intravenous iron sucrose [49]. However, the paper authors acknowledged some study limitations, such as the premature cessation of the oral iron treatment, and the excessively short study follow-up period (3 weeks), that might have been insufficient to properly evaluate the oral iron treatment effect in this population. Of note, the authors highlighted the good safety profile of both treatments [49].

IPS has been further evaluated as a therapeutic option for postoperative anemia [51-53]. Improvement in IDA symptomatology and a normalization of all the hematologic parameters were observed with IPS in the three clinical trials.
Significant increases in serum ferritin and serum iron concentrations clearly indicate a good iron absorption profile of IPS, in accordance with those results obtained in other studies. IPS responds to the required characteristics that would define an ideal oral iron therapy for treating postoperative anemia, according to the International Consensus Statement on the management of postoperative anemia after major surgical procedures [50]: good intestinal absorption despite the high serum hepcidin levels caused by the inflammatory reaction, optimal tolerability profile (especially with a low incidence of GI side-effects), and potentially good treatment adherence.

Due to its multifactorial etiology and its associated morbidity, IDA treatment in the elderly population may become a rather challenging task. Even if Guidelines and experts recommend starting with oral iron therapy, a scarce iron absorption along with an increase in related adverse events can negatively impact on the treatment outcomes $[5,7$, $14,30,77]$. IPS has been shown to be safe and effective in the elderly population from the two long-term clinical trials reviewed in this publication [42, 58]. Both clinical and hematologic parameters significantly improved in an early and sustained fashion along the two study follow-up periods. Interestingly, significant differences in hematologic parameters, like $\mathrm{Hb}$ and serum ferritin, were observed in the IPS group versus the FS group, in the Liguori clinical trial, presumably reflecting a better iron absorption and greater iron storage [42]. These findings are relevant because traditionally ferrous compounds have been regarded to have a better iron absorption than the ferric salts.

Moreover, study subjects' drop-out rates were very low, which could be mainly due to its higher tolerability profile and to the IPS liquid formulation that presents a clear administration advantage in terms of compliance for the elderly population (allowing an easier drug titration if needed, easier intake for patients with swallowing problems and its easily differentiable from other drugs in multi-medicated patients) among other possible reasons.

The study performed in a sample of ID blood donors comparing IPS with FS showed likewise a significant superior increase of hematologic parameters that indicate a higher iron absorption, like $\mathrm{Hb}$ and serum ferritin [65]. These results are consistent with findings in studies conducted with IPS in different adult populations suffering from ID and IDA. Of note, hematologic parameters normalization was achieved quite fast with IPS, while this effect may take much longer with ferrous salts $[19,64]$.

Two studies assessed the effect of IPS in athletes, confirming that a dose of $80 \mathrm{mg}$ daily of IPS can be useful to either prevent a decline in hematologic parameters, along with a reduction in accumulated stress in response to exercise intensity (as measured by serum cortisol) or to successfully treat ID, increasing and normalizing hematologic parameters, in a relative short time $[67,68]$.

Overall, IPS showed very good safety and tolerability profiles in all the studies conducted in adults with ID and IDA, that evaluated the study treatment tolerability $(70 \%$ of 
the included studies). Variations in the incidence of adverse events favoring IPS were observed in three studies comparing IPS with ferrous salts [40-42]; while, in the largest study conducted with IPS in a general adult population, a better tolerability profile was observed with IPS versus FS, with a significantly lower number of reported adverse events, as well as a shorter duration and later onset [42]. These results endorse the lack of GI mucosal damage with the use of IPS, as it has been previously hypothesized in preclinical studies $[71,72]$, results that were later confirmed in a meta-analysis [78] and in a recently published systematic review [12].

Altogether, IPS, with an evidence based clinical efficacy comparable to the gold standard, its lack of serum hepcidin increase induction, and an improved safety and tolerability profile, that might enhance treatment adherence, should be specially regarded as an utmost convenient drug to treat IDA patients with coexistence of multiple aetiologic factors.

Some methodologic limitations regarding the included studies in this review must be acknowledged. Most of the studies were conducted for a short period of time with a limited follow-up time, and this may have influenced the study outcomes, for instance, not reaching the statistical significance in some cases. However, a constant trend was frequently reported. In addition, study objectives differ among the studies. It must be mentioned that $30 \%$ of the selected trials did not reported any tolerability and safety data. A further limitation are the different study populations, that make the review difficult to draw conclusions. However, the great consistency in the efficacy (both clinical and hematologic) and tolerability results supports the validity of all the observations that have been commented in this narrative review.

\section{Serum hepcidin induction from baseline (mean $\pm S D)$}

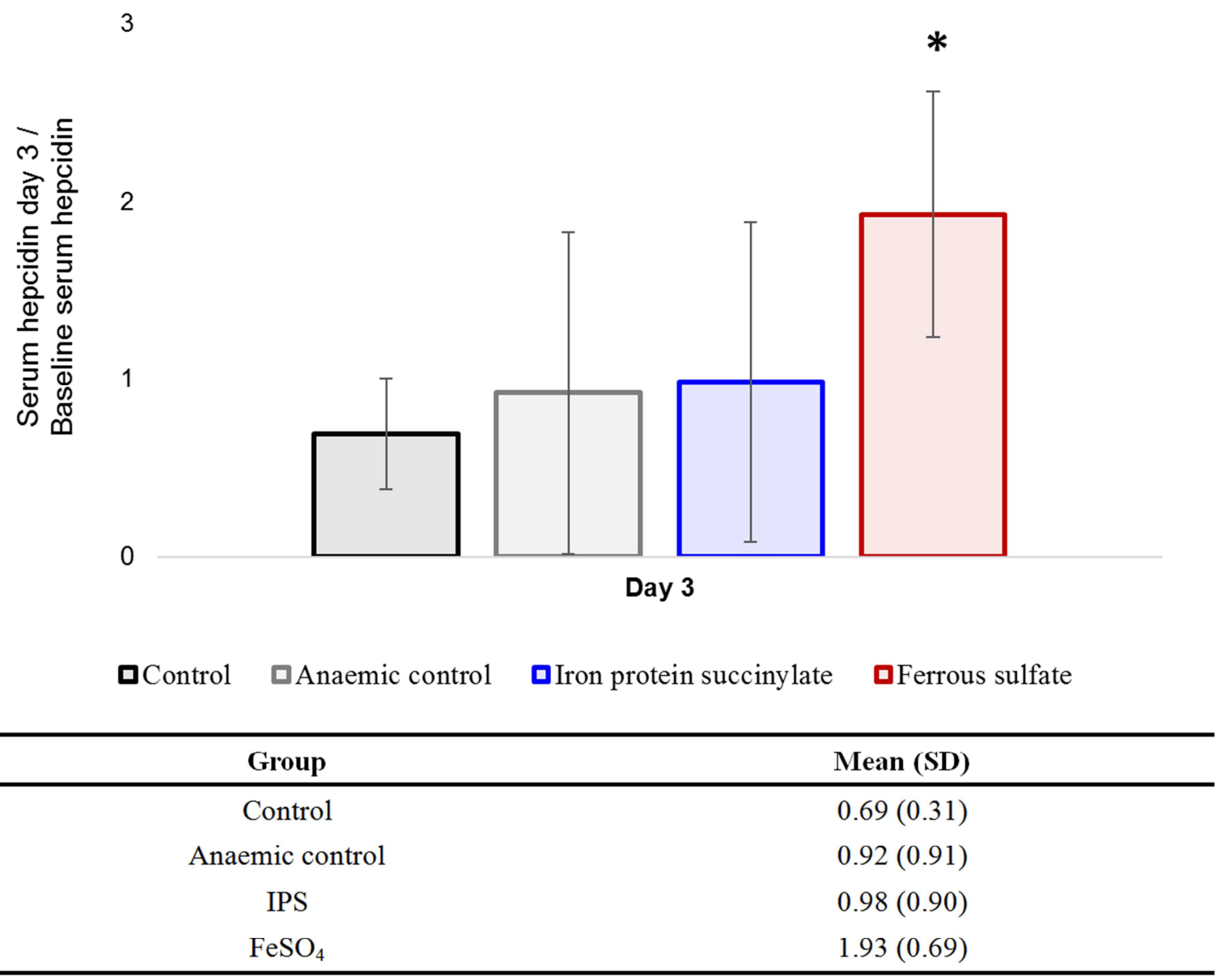

IPS: Iron Protein Succinylate

Figure 2. Serum hepcidin / Baseline serum hepcidin ratio following treatment with 200 mg of IPS or FeSO $\mathrm{F}_{4}$ compared to two control groups without iron treatment (anemic and non-anemic).

Serum hepcidin levels after 3 days of supplementation compared to baseline levels (a mean ratio of 1 means that the level is the same as at baseline). IPS group maintains hepcidin levels at a similar range to baseline levels after 3 days of iron supplementation, while ferrous sulphate increases hepcidin levels to around twice the baseline levels after 3 days of supplementation.

* $\mathrm{p}<0.05$, as compared to control group by a Kruskal-Wallis with Dunnett's multiple comparison test. 
Table 4. Studies with oral IPS in iron deficiency associated to diverse conditions in adults.

\begin{tabular}{|c|c|c|c|c|c|c|c|}
\hline Study & Design & Treatments & Duration & Population & Objectives & Efficacy Results & Safety Results \\
\hline Ambrosini & $\begin{array}{l}\text { Randomized, } \\
\text { controlled, } \\
\text { double-blind } \\
\text { clinical trial }\end{array}$ & $\begin{array}{l}\text { A- IPS } 80 \mathrm{mg} \\
\mathrm{Fe}^{3+} \text { daily } \\
\text { B- IG } 125 \mathrm{mg} \\
\mathrm{Fe}^{3+} \text { daily }\end{array}$ & $\begin{array}{l}28 \text { days } \\
\text { (3-week } \\
\text { stage } \\
\text { race) }\end{array}$ & $\begin{array}{l}30 \text { patients with } \\
\text { ID due to GI } \\
\text { conditions, } \\
\text { corrected with } \\
\text { surgery or } \\
\text { drugs: } 15 \text {, IPS; } \\
15, \text { FG }\end{array}$ & $\begin{array}{l}\text { 1) Hematologic } \\
\text { parameters } \\
\text { 2) Serum } \\
\text { cortisol \& } \\
\text { biochemical } \\
\text { muscle } \\
\text { biomarkers }\end{array}$ & $\begin{array}{l}\text { 1) Both groups significantly increased } \\
\text { the following parameters, after 1-month } \\
\text { treatment: Hb, SI, HCT, MCV, MCH, } \\
\text { MCHC. Results were more marked } \\
\text { with IPS } \\
\text { 2) Clinical symptomatology (asthenia, } \\
\text { fatigue, and cutaneous-mucous } \\
\text { paleness) improved in both groups, } \\
\text { although more markedly with IPS } \\
\text { 1) Hematologic parameters (Hb, HCT, } \\
\text { SI, and SF) values were preserved in the } \\
\text { IPS treated group. Significant } \\
\text { differences (p<0.05) between IPS and } \\
\text { placebo groups were observed. } \\
\text { 2) The hematologic values in IPS group } \\
\text { were shown to have a positive } \\
\text { relationship with muscular recovery } \\
\text { parameters and a negative correlation } \\
\text { with cortisol levels (indicating a lower } \\
\text { level of effort-induced stress). }\end{array}$ & $\begin{array}{l}\text { 3) No adverse } \\
\text { events were } \\
\text { reported } \\
\text { Not reported }\end{array}$ \\
\hline Danisi & $\begin{array}{l}\text { Randomized } \\
\text { open-label clinical } \\
\text { trial }\end{array}$ & $\begin{array}{l}\text { A- IPS } 80 \mathrm{mg} \\
\mathrm{Fe}^{3+} \text { daily } \\
\mathrm{B}-\mathrm{EF} \text { (eq. } 80 \\
\mathrm{mg} \mathrm{Fe}^{3+} \text { ) daily }\end{array}$ & 30 days & $\begin{array}{l}30 \text { adult } \\
\text { patients of both } \\
\text { sexes, with IDA } \\
\text { secondary to } \\
\text { several } \\
\text { pathologies } \\
\text { (mean age: } 68 \text { ): } \\
\text { 15, IPS; 15, EF }\end{array}$ & $\begin{array}{l}\text { 1) Hematologic } \\
\text { parameters } \\
\text { 2) Clinical } \\
\text { symptomatology } \\
\text { due to ID } \\
\text { 3) Tolerability }\end{array}$ & $\begin{array}{l}\text { 1) Both groups significantly increased } \\
\text { the following parameters, after 1-month } \\
\text { treatment: Hb, SI, HCT, MCV, MCH, } \\
\text { MCHC and RBC. Statistically } \\
\text { significant differences in favour of IPS } \\
\text { were observed in Hb, RBC, MCV, } \\
\text { MCH, and MCHC. } \\
\text { 2) Clinical symptomatology (asthenia, } \\
\text { skin pallor, mucosa pallor, fatigue) was } \\
\text { improved in the IPS group, while only } \\
\text { asthenia and fatigue showed } \\
\text { improvements with EF. } \\
\text { 1) Both treatments improved } \\
\text { hematologic parameters (RBC, Hb, and } \\
\text { SI); but only IPS achieved a statistically } \\
\text { significant increase in the iron reserves } \\
\text { (SF). } \\
\text { 2) Both drugs demonstrated a } \\
\text { considerable iron absorption (Gordeuk } \\
\text { formula). }\end{array}$ & $\begin{array}{l}\text { 3) Few and mild } \\
\text { adverse events were } \\
\text { reported in both } \\
\text { groups. Both drugs' } \\
\text { tolerability was } \\
\text { regarded excellent } \\
\text { by study subjects. } \\
\text { Not reported }\end{array}$ \\
\hline Di Giacomo & $\begin{array}{l}\text { Randomized } \\
\text { open-label clinical } \\
\text { trial }\end{array}$ & $\begin{array}{l}\text { A- IPS } 80 \mathrm{mg} \\
\mathrm{Fe}^{3+} \text { daily } \\
\mathrm{B}-\mathrm{EF} \text { (eq. } 80 \\
\mathrm{mg} \mathrm{Fe} \mathrm{F}^{3+} \text { ) daily } \\
\mathrm{C}-\mathrm{FS} 105 \mathrm{mg} \\
\mathrm{Fe}^{2+} \text { daily }\end{array}$ & $\begin{array}{l}\text { Two } \\
\text { periods: } \\
\text { 1.- PK } \\
\text { study of } 6 \\
\text { hs on } 3 \\
\text { different } \\
\text { days. } \\
2 .-28 \\
\text { days } \\
\text { (efficacy). }\end{array}$ & $\begin{array}{l}-10 \text { adult } \\
\text { patients with } \\
\text { IDA }\left(1^{\text {st }}\right. \\
\text { period }) \text { : all } \\
\text { treated with the } \\
\text { three drugs. } \\
-30 \text { outpatients } \\
\text { with IDA }\left(2^{\text {nd }}\right. \\
\text { period }): 10, \\
\text { IPS; } 10, \text { EF; } 10 \text {, } \\
\text { FS. }\end{array}$ & $\begin{array}{l}\text { 1) Serum Iron } \\
\text { concentrations at } \\
7 \text { time points } \\
\text { (assessed in a } \\
\text { loading curve } \\
\text { following the } \\
\text { drug } \\
\text { administration). } \\
\text { 2) Hematologic } \\
\text { parameters. } \\
\text { 3) Iron absorption } \\
\text { (estimation based } \\
\text { on the SI increase } \\
\text { observed during } \\
\text { treatment). }\end{array}$ & $\begin{array}{l}\text { 1) Faster initial increase in SI } \\
\text { concentration levels with FS, but IPS } \\
\text { achieved higher and more sustained } \\
\text { iron concentration levels along the } \\
\text { whole PK assessment period ( } 6 \text { hours). } \\
\text { 2) The three preparations showed } \\
\text { significant increases in the following } \\
\text { hematologic parameters: Hb, SI, TIBC, } \\
\text { and TSAT. } \\
\text { 3) IPS achieved a numerically higher } \\
\text { percentage of iron absorbed ( } 6.1 \%) \text { than } \\
\text { FS }(5.9 \%) \text { and EF }(5.5 \%) \text {. }\end{array}$ & Not reported \\
\hline Di Somma & $\begin{array}{l}\text { Randomized } \\
\text { single-blind } \\
\text { clinical trial }\end{array}$ & $\begin{array}{l}\text { A- IPS } 80 \mathrm{mg} \\
\mathrm{Fe}^{3+} \text { daily } \\
\mathrm{B}-\mathrm{EF}(\text { eq. } 80 \\
\mathrm{mg} \mathrm{Fe}{ }^{3+} \text { ) daily }\end{array}$ & 30 days & $\begin{array}{l}20 \text { adult } \\
\text { patients of both } \\
\text { sexes, with } \\
\text { several } \\
\text { pathologies } \\
\text { (mean age: } 40 \text { ): } \\
10 \text { IPS; } 10 \mathrm{EF}\end{array}$ & $\begin{array}{l}\text { 1) Hematologic } \\
\text { parameters } \\
\text { 2) Iron } \\
\text { absorption } \\
\text { (Gordeuk } \\
\text { formula) } \\
\text { 3) Tolerability }\end{array}$ & $\begin{array}{l}\text { 1) All the hematologic parameters (Hb, } \\
\mathrm{HCT}, \mathrm{RBC}, \mathrm{SI}, \mathrm{MCV}, \mathrm{MCHC}, \mathrm{SF}) \\
\text { improved with IPS, except transferrin. } \\
\text { All the hematologic parameters } \\
\text { improved with EF, except transferrin } \\
\text { and HCT. } \\
\text { Hb was significantly more improved } \\
\text { with IPS. } \\
\text { 2) Iron absorption was estimated to be } \\
\text { significantly higher with IPS }(9.84 \%) \\
\text { than with EF }(5.38 \%) \text {. }\end{array}$ & $\begin{array}{l}\text { 3) Tolerability was } \\
\text { very good in both } \\
\text { treatment groups. }\end{array}$ \\
\hline
\end{tabular}




\begin{tabular}{|c|c|c|c|c|c|c|c|}
\hline Study & Design & Treatments & Duration & Population & Objectives & Efficacy Results & Safety Results \\
\hline Duntas & $\begin{array}{l}\text { Randomized } \\
\text { single-blind } \\
\text { clinical trial }\end{array}$ & $\begin{array}{l}\text { A- IPS } 80 \mathrm{mg} \\
\mathrm{Fe}^{3+} \text { daily } \\
\text { B- LT4 } 100 \mu \mathrm{g} \\
\text { daily } \\
\text { C- IPS } 80 \mathrm{mg} \\
\mathrm{Fe}^{3+} \text { daily }+ \\
\text { LT4 } 100 \mu \mathrm{g} \\
\text { daily }\end{array}$ & 90 days & $\begin{array}{l}33 \\
\text { premenopausal } \\
\text { women with } \\
\text { subclinical } \\
\text { hypothyroidism } \\
\text { (mean age: } 37 \text { ): } \\
\text { 11, IPS; 11, } \\
\text { LT4; } 11 \text {, IPS + } \\
\text { LT4 }\end{array}$ & $\begin{array}{l}\text { 1) Hematologic } \\
\text { parameters } \\
\text { 2) Clinical } \\
\text { symptomatology } \\
\text { due to ID } \\
\text { 3) Tolerability }\end{array}$ & $\begin{array}{l}\text { 1). IPS and IPS + LT4 patients showed a } \\
\text { marked (and significant versus } \\
\text { baseline) increase in SI, Hb and HCT. } \\
\text { At study completion, the IPS + LT4 } \\
\text { group achieved significantly better } \\
\text { results LT4 only group. } \\
\text { 2) Clinical symptomatology (fatigue, } \\
\text { dizziness, and general performance) } \\
\text { was also most improved in the IPS + } \\
\text { LT4 group. }\end{array}$ & $\begin{array}{l}\text { 3) Tolerability was } \\
\text { regarded as very } \\
\text { good in the three } \\
\text { treatment groups. }\end{array}$ \\
\hline $\begin{array}{l}\text { Gruppo } \\
\text { Italiano }\end{array}$ & $\begin{array}{l}\text { Single-cohort } \\
\text { prospective study } \\
\text { (compared with a } \\
\text { control group of } \\
\text { healthy elderly } \\
\text { subjects) }\end{array}$ & $\begin{array}{l}\text { IPS } 80 \mathrm{mg} \mathrm{Fe}^{3+} \\
\text { daily }\end{array}$ & $\begin{array}{l}30-60 \\
\text { days, with } \\
\text { a } \\
\text { follow-up } \\
\text { period up } \\
\text { to } 12 \\
\text { months. }\end{array}$ & $\begin{array}{l}81 \\
\text { institutionalized } \\
\text { elderly patients } \\
\text { with iron } \\
\text { deficiency. } \\
\text { (control group: } \\
81 \text { healthy } \\
\text { elderly } \\
\text { subjects). }\end{array}$ & $\begin{array}{l}\text { 1) Hematologic } \\
\text { parameters } \\
\text { 2) Clinical } \\
\text { symptomatology } \\
\text { 3) Tolerability }\end{array}$ & $\begin{array}{l}\text { 1) Hematologic parameters } \\
\text { significantly improved versus baseline } \\
\text { values in the study group, whereas an } \\
\text { opposite trend was observed in the } \\
\text { control group. } \\
\text { 2) Clinical symptomatology } \\
\text { significantly improved versus baseline } \\
\text { values in the study group, whereas an } \\
\text { opposite trend was observed in the } \\
\text { control group. }\end{array}$ & $\begin{array}{l}\text { 3) Both clinician } \\
\text { and patient } \\
\text { evaluations } \\
\text { regarded IPS } \\
\text { tolerability (based } \\
\text { on the low } \\
\text { incidence of } \\
\text { adverse events) as } \\
\text { very high. }\end{array}$ \\
\hline Kim & $\begin{array}{l}\text { Randomized } \\
\text { open-label clinical } \\
\text { trial }\end{array}$ & $\begin{array}{l}\text { A- IPS } 120 \mathrm{mg} \\
\mathrm{Fe}^{3+} \text { daily } \\
\text { (beginning } 3 \\
\text { weeks before } \\
\text { surgery) } \\
\text { B- I.V. IS } 200 \\
\text { mg x } 3 \text { times / } \\
\text { week } \\
\text { (beginning } 3 \\
\text { weeks before } \\
\text { surgery) }\end{array}$ & 3 weeks & $\begin{array}{l}76 \text { IDA patients } \\
\text { with } \\
\text { menorrhagia: } \\
37 \text {, IPS; 39, IS }\end{array}$ & $\begin{array}{l}\text { 1) Hematologic } \\
\text { parameters } \\
\text { 2) Tolerability }\end{array}$ & $\begin{array}{l}\text { 1) At study completion, although both } \\
\text { groups improved hematologic } \\
\text { parameters, the i.v. IS group showed } \\
\text { statistically higher increases in } \mathrm{Hb}, \mathrm{SF} \\
\text { and MCV than the oral IPS group (a } \\
\text { premature cessation of the oral iron arm } \\
\text { and the short study duration were } \\
\text { regarded as important methodologic } \\
\text { limitations by the study authors). }\end{array}$ & $\begin{array}{l}\text { 3) Tolerability was } \\
\text { considered very } \\
\text { good in both } \\
\text { treatment groups. }\end{array}$ \\
\hline Landucci & $\begin{array}{l}\text { Randomized } \\
\text { open-label clinical } \\
\text { trial }\end{array}$ & $\begin{array}{l}\text { A- IPS } 80 \mathrm{mg} \\
\mathrm{Fe}^{3+} \text { daily } \\
\mathrm{B}-\mathrm{FS} 105 \mathrm{mg} \\
\mathrm{Fe}^{2+} \text { daily }\end{array}$ & 30 days & $\begin{array}{l}40 \text { blood donors } \\
\text { (mean age: } 36 \text { ): } \\
\text { 20, IPS; 20, FS }\end{array}$ & $\begin{array}{l}\text { 1) Hematologic } \\
\text { parameters } \\
\text { 2) Iron } \\
\text { absorption } \\
\text { (Gordeuk } \\
\text { formula) } \\
\text { 3) Tolerability }\end{array}$ & $\begin{array}{l}\text { 1) IPS significantly increased HCT, SI } \\
\text { and SF; while FS significantly } \\
\text { increased only SF, at study completion. } \\
\text { 2) IPS induced a greater iron absorption } \\
\text { than FS: } 18.7 \% \text { vs } 6.4 \% \text {, respectively. }\end{array}$ & $\begin{array}{l}\text { 3) Tolerability was } \\
\text { very good for both } \\
\text { treatments (only } \\
\text { one mild adverse } \\
\text { event por group). }\end{array}$ \\
\hline Liguori & $\begin{array}{l}\text { Randomized, } \\
\text { placebo-controlled, } \\
\text { double-dummy, } \\
\text { clinical trial }\end{array}$ & $\begin{array}{l}\text { A- IPS } 120 \mathrm{mg} \\
\mathrm{Fe}^{3+} \text { daily } \\
\text { B- ER FS } 105 \\
\mathrm{mg} \mathrm{Fe}^{2+} \text { daily }\end{array}$ & 60 days & $\begin{array}{l}\text { 1,095 patients } \\
\text { with ID or IDA: } \\
\text { 549, IPS; 546, } \\
\text { ER FS }\end{array}$ & $\begin{array}{l}\text { 1) Hematologic } \\
\text { parameters } \\
\text { 2) Clinical } \\
\text { symptomatology } \\
\text { due to ID and } \\
\text { IDA (including } \\
\text { an overall } \\
\text { clinical rating) } \\
\text { 3) Tolerability }\end{array}$ & $\begin{array}{l}\text { 1) At day } 60 \text {, normalization of the main } \\
\text { hematologic parameters was observed } \\
\text { in both groups, albeit with greater } \\
\text { values of Hb, HCT, Ferritin, and IS in } \\
\text { the IPS group } \\
\text { 2) Asthenia, fatigue, and skin and } \\
\text { mucosal paleness significantly } \\
\text { improved with IPS vs ER FS. Overall } \\
\text { clinical rating was significantly in favor } \\
\text { of IPS }(78.9 \%) \text { vs ER FS }(67.6 \%)\end{array}$ & $\begin{array}{l}\text { 3) A better } \\
\text { tolerability profile } \\
\text { was observed with } \\
\text { IPS, with a } \\
\text { significantly lower } \\
\text { number of reported } \\
\text { adverse events; with } \\
\text { shorter duration and } \\
\text { later onset }\end{array}$ \\
\hline Manfredi & $\begin{array}{l}\text { Prospective, } \\
\text { single-arm clinical } \\
\text { trial }\end{array}$ & $\begin{array}{l}\text { IPS } 80 \mathrm{mg} \mathrm{Fe}^{3+} \\
\text { daily }\end{array}$ & 30 days & $\begin{array}{l}80 \text { patients with } \\
\text { IDA from } \\
\text { diverse etiology }\end{array}$ & $\begin{array}{l}\text { 1) Hematologic } \\
\text { parameters } \\
\text { 2) Tolerability }\end{array}$ & $\begin{array}{l}\text { 1) At study end, significant increases } \\
\text { were observed in the following } \\
\text { parameters: Hb, HCT, SI, RBC, MCHC, } \\
\text { and TSAT Hematologic improvements } \\
\text { were reported in the subgroup analysis }\end{array}$ & $\begin{array}{l}\text { 2) Overall } \\
\text { tolerability was } \\
\text { excellent according } \\
\text { to the clinical } \\
\text { judgement (adverse } \\
\text { events were reported } \\
\text { in } 7.5 \% \text { of the } \\
\text { subjects) }\end{array}$ \\
\hline Pedrazzoli & $\begin{array}{l}\text { Randomized } \\
\text { single-blind } \\
\text { clinical trial }\end{array}$ & $\begin{array}{l}\text { A- IPS } 80 \mathrm{mg} \\
\mathrm{Fe}^{3+} \text { daily } \\
\mathrm{B}-\mathrm{IG} 125 \mathrm{mg} \\
\mathrm{Fe}^{3+} \text { daily }\end{array}$ & 60 days & $\begin{array}{l}40 \text { adult } \\
\text { patients with } \\
\text { IDA from } \\
\text { diverse } \\
\text { pathologies } \\
\text { (mean age: } 41 \text { ): } \\
\text { 20, IPS; } 20, \text { IG }\end{array}$ & $\begin{array}{l}\text { 1) Hematologic } \\
\text { parameters } \\
\text { 2) Tolerability }\end{array}$ & $\begin{array}{l}\text { 1) At wo months, both drugs } \\
\text { significantly increased the following } \\
\text { parameters: HCT, Hb, SI, SF, RBC, and } \\
\text { MCV. However, changes in some of the } \\
\text { parameters (SI, SF, TIBC and MCV) } \\
\text { were observed earlier with IPS. } \\
\text { Furthermore, greater improvements in } \\
\text { favour of IPS were observed in Hb, } \\
\text { HCT, SF and reticulocyte count. }\end{array}$ & $\begin{array}{l}\text { 2) A better } \\
\text { tolerability profile } \\
\text { was observed in IPS } \\
\text { treated patients. }\end{array}$ \\
\hline Piccoli & $\begin{array}{l}\text { Randomized, } \\
\text { double-blind, }\end{array}$ & $\begin{array}{l}\text { A- IPS } 120 \mathrm{mg} \\
\mathrm{Fe}^{3+} \text { daily }\end{array}$ & 60 days & $\begin{array}{l}30 \text { patients with } \\
\text { CKD }\end{array}$ & $\begin{array}{l}\text { 1) Hematologic } \\
\text { parameters }\end{array}$ & $\begin{array}{l}\text { 1) Both at } 30 \text { days and, more markedly, } \\
\text { at the end of the study, most of the }\end{array}$ & $\begin{array}{l}\text { 2) tolerability was } \\
\text { very good and }\end{array}$ \\
\hline
\end{tabular}




\begin{tabular}{|c|c|c|c|c|c|c|c|}
\hline Study & Design & Treatments & Duration & Population & Objectives & Efficacy Results & Safety Results \\
\hline & $\begin{array}{l}\text { placebo-controlled } \\
\text { clinical trial }\end{array}$ & $\begin{array}{l}\text { B- Placebo, } \\
\text { daily }\end{array}$ & & $\begin{array}{l}\text { (ND-CKD, } \\
\mathrm{n}=14 ; \text { and } \mathrm{CKD} \\
\text { on } \\
\text { hemodialysis, } \\
\mathrm{n}=16) \text { who had } \\
\text { developed ID. } \\
\text { IPS, } \mathrm{n}=14 ; \\
\text { placebo, } \mathrm{n}=16\end{array}$ & 2) Tolerability & $\begin{array}{l}\text { hematologic parameters significantly } \\
\text { improved in the IPS arm compared to } \\
\text { the placebo group, in both ND-CKD } \\
\text { and D-CKD patients. }\end{array}$ & $\begin{array}{l}\text { comparable } \\
\text { between the IPS } \\
\text { and the placebo } \\
\text { groups. }\end{array}$ \\
\hline Pogliani & $\begin{array}{l}\text { Randomized } \\
\text { single-blind } \\
\text { clinical trial }\end{array}$ & $\begin{array}{l}\text { A- IPS } 80 \mathrm{mg} \\
\mathrm{Fe}^{3+} \text { daily } \\
\mathrm{B}-\text { IPS } 120 \mathrm{mg} \\
\mathrm{Fe}^{3+} \text { daily } \\
\mathrm{C}-\mathrm{ER} \text { FS } 105 \\
\mathrm{mg} \mathrm{Fe}{ }^{2+} \text { daily }\end{array}$ & 60 days & $\begin{array}{l}54 \text { adult } \\
\text { patients with } \\
\text { IDA from } \\
\text { diverse } \\
\text { etiologies } \\
\text { (mean age, 57): } \\
22 \text {, IPS } 80 ; 19 \text {, } \\
\text { IPS } 120 ; 13, \text { ER } \\
\text { FS }\end{array}$ & $\begin{array}{l}\text { 1) Hematologic } \\
\text { parameters } \\
\text { 2) Tolerability }\end{array}$ & $\begin{array}{l}\text { 1) At study completion, Hb, HCT, SI, } \\
\text { and RBC had significantly improved in } \\
\text { the three study groups, although } \\
\text { increases were markedly greater in both } \\
\text { IPS groups when compared with ER FS } \\
\text { group. }\end{array}$ & $\begin{array}{l}\text { 2) A better } \\
\text { tolerability profile } \\
\text { was observed in both } \\
\text { IPS treated groups } \\
\text { compared with ER } \\
\mathrm{FS} \text {, with significantly } \\
\text { fewer reported } \\
\text { adverse events } \\
\text { (p<0.001). } 4 \text { patients } \\
\text { in the ER FS group } \\
\text { discontinued the } \\
\text { study because of } \\
\text { tolerability } \\
\text { complaints. }\end{array}$ \\
\hline Trojachanec & $\begin{array}{l}\text { Prospective, } \\
\text { open-label, } \\
\text { two-cohort trial }\end{array}$ & $\begin{array}{l}\text { A- IPS } 40-80 \\
m g \mathrm{Fe}^{3+} \text { daily }\end{array}$ & 60 days & $\begin{array}{l}40 \text { healthy } \\
\text { females: } 20 \text {, } \\
\text { sportswomen } \\
\text { (age range: } \\
20-24) \text { vs } 20 \\
\text { students (age } \\
\text { range: } 20-23) \text {. }\end{array}$ & $\begin{array}{l}\text { 1) Hematologic } \\
\text { parameters }\end{array}$ & $\begin{array}{l}\text { 1) After two months of IPS treatment, } \\
\text { the athletes' group significantly } \\
\text { improved } \mathrm{Hb} \text { and SI versus baseline, } \\
\text { and SI versus the control group. }\end{array}$ & Not reported \\
\hline Veneroni & $\begin{array}{l}\text { Randomized. } \\
\text { Double-blind } \\
\text { clinical trial }\end{array}$ & $\begin{array}{l}\text { A- IPS, } 40 \mathrm{mg} \\
\mathrm{Fe}^{3+} \text { daily } \\
\mathrm{B} \text { - iron protein } \\
\text { derived from } \\
\text { saccharomyces } \\
\text { cerevisiae } \\
\text { cultures, Fe } 40 \\
\text { mg, daily }\end{array}$ & 30 days & $\begin{array}{l}40 \text { patients } \\
\text { suffering from } \\
\text { post-surgical } \\
\text { ID: } 20 \text {, IPS; } 20 \text {, } \\
\text { iron protein } \\
\text { derived from } \\
\text { saccharomyces } \\
\text { cerevisiae }\end{array}$ & $\begin{array}{l}\text { 1) Hematologic } \\
\text { parameters } \\
\text { 2) Clinical } \\
\text { symptomatology } \\
\text { due to ID } \\
\text { 3) Tolerability }\end{array}$ & $\begin{array}{l}\text { 1) The following parameters were } \\
\text { increased in both study groups: HB, RBC, } \\
\text { HCT, SI, MCH, reticulocytes, and serum } \\
\text { ferritin and transferrin. No differences } \\
\text { between groups were observed } \\
\text { 2) Clinical symptomatology was } \\
\text { improved in both groups, with no } \\
\text { differences between them }\end{array}$ & $\begin{array}{l}\text { 3) Overall reported } \\
\text { tolerability was } \\
\text { very good for all the } \\
\text { patients }\end{array}$ \\
\hline
\end{tabular}

\section{Conclusion}

Iron protein succinylate (IPS), an iron complex containing ferric iron engulfed in an electronegative protein carrier, that precipitates in acid $\mathrm{pH}$ and becomes soluble at neutral to alkaline $\mathrm{pH}$ levels, has demonstrated to protect the gastrointestinal mucosa from eventual damage, improve intestinal iron absorption, and have a neutral effect on hepcidin levels.

Regardless of the different characteristics of the adult and elderly populations from the reviewed studies, IPS compares favorably in efficacy and safety (especially, GI tolerability) with other currently available oral iron preparations, especially ferrous salts. IPS has shown a fast and steady improvement in hematologic parameters (that reflect a better iron absorption), and a lower incidence of adverse events, in a wide range of conditions prevalent among adults that cause an absolute or functional iron deficiency, and they may consequently lead to the development of iron deficiency anemia. These results confirm the previously reported pharmacological profile of IPS.

Finally, follow-up of IPS in the reviewed populations as well as further research of IPS in other diseases should be made.

\section{Acknowledgements}

The author wishes to thank Javier Leal and Ignacio Arístegui for their assistance in the manuscript writing and review.

\section{References}

[1] Kassebaum NJ, Jasrasaria R, Naghavi M, Wulf SK, Johns N, Lozano R, et al. A systematic analysis of global anemia burden from 1990 to 2010. Blood. 2014; 123 (5): 615-24.

[2] Camaschella C. Iron-Deficiency Anemia. N Engl J Med. 2015; 373 (5): 485-6.

[3] Stoltzfus RJ. Iron deficiency: global prevalence and consequences. Food Nutr Bull. 2003; 24 (4 Suppl): S99-103.

[4] Levi M, Rosselli M, Simonetti M, Brignoli O, Cancian M, Masotti A, et al. Epidemiology of iron deficiency anaemia in four European countries: a population-based study in primary care. Eur J Haematol. 2016; 97 (6): 583-93.

[5] Burton JK, Yates LC, Whyte L, Fitzsimons E, Stott DJ. New horizons in iron deficiency anaemia in older adults. Age Ageing. 2020. 
[6] Camaschella C. New insights into iron deficiency and iron deficiency anemia. Blood Rev. 2017; 31 (4): 225-33.

[7] Peyrin-Biroulet L, Williet N, Cacoub P. Guidelines on the diagnosis and treatment of iron deficiency across indications: a systematic review. Am J Clin Nutr. 2015; 102 (6): 1585-94.

[8] Santiago P. Ferrous versus Ferric Oral Iron Formulations for the Treatment of Iron Deficiency: A Clinical Overview. The Scientific World Journal. 2012; 2012: 846824.

[9] Tolkien Z, Stecher L, Mander AP, Pereira DI, Powell JJ. Ferrous sulfate supplementation causes significant gastrointestinal side-effects in adults: a systematic review and meta-analysis. PLoS One. 2015; 10 (2): e0117383.

[10] Moretti D, Goede JS, Zeder C, Jiskra M, Chatzinakou V, Tjalsma $\mathrm{H}$, et al. Oral iron supplements increase hepcidin and decrease iron absorption from daily or twice-daily doses in iron-depleted young women. Blood. 2015; 126 (17): 1981-9.

[11] Stoffel NU, Cercamondi CI, Brittenham G, Zeder C, Geurts-Moespot AJ, Swinkels DW, et al. Iron absorption from oral iron supplements given on consecutive versus alternate days and as single morning doses versus twice-daily split dosing in iron-depleted women: two open-label, randomised controlled trials. The Lancet Haematology. 2017; 4 (11): e524-e33.

[12] Martinez Frances A, Leal Martinez-Bujanda J. Efficacy and tolerability of oral iron protein succinylate: a systematic review of three decades of research. Curr Med Res Opin. 2020: $1-11$.

[13] Urso K, Leal Martínez-Bujanda J, Del Prado JM. Iron Protein Succinylate in the Management of Iron Deficiency Anemia: A Comparative Study with Ferrous Sulphate at Low and High Therapeutic Doses. Nutrients. 2021; 13 (3).

[14] Camaschella C. Iron deficiency. Blood. 2019; 133 (1): 30-9.

[15] De Franceschi L, Iolascon A, Taher A, Cappellini MD. Clinical management of iron deficiency anemia in adults: Systemic review on advances in diagnosis and treatment. Eur J Intern Med. 2017; 42: 16-23.

[16] Elstrott B, Khan L, Olson S, Raghunathan V, DeLoughery T, Shatzel JJ. The role of iron repletion in adult iron deficiency anemia and other diseases. Eur J Haematol. 2020; 104 (3): 153-61.

[17] Low MS, Speedy J, Styles CE, De-Regil LM, Pasricha SR. Daily iron supplementation for improving anaemia, iron status and health in menstruating women. Cochrane Database Syst Rev. 2016; 4: Cd009747.

[18] Cable RG, Spencer BR. Iron supplementation by blood donors: demographics, patterns of use, and motivation. Transfusion. 2019; 59 (9): 2857-64.

[19] Drexler C, Macher S, Lindenau I, Holter M, Moritz M, Stojakovic T, et al. High-dose intravenous versus oral iron in blood donors with iron deficiency: The IronWoMan randomized, controlled clinical trial. Clin Nutr. 2020; 39 (3): 737-45.

[20] Zalpuri S, Schotten N, Baart AM, van de Watering LM, van den Hurk K, van Kraaij MGJ. Iron deficiency-related symptoms in whole blood donors: a systematic review. Transfusion. 2019; 59 (10): 3275-87.
[21] Coates A, Mountjoy M, Burr J. Incidence of Iron Deficiency and Iron Deficient Anemia in Elite Runners and Triathletes. Clin J Sport Med. 2017; 27 (5): 493-8.

[22] Pedlar CR, Brugnara C, Bruinvels G, Burden R. Iron balance and iron supplementation for the female athlete: A practical approach. Eur J Sport Sci. 2018; 18 (2): 295-305.

[23] Rubeor A, Goojha C, Manning J, White J. Does Iron Supplementation Improve Performance in Iron-Deficient Nonanemic Athletes? Sports health. 2018; 10 (5): 400-5.

[24] Sim M, Garvican-Lewis LA, Cox GR, Govus A, McKay AKA, Stellingwerff $\mathrm{T}$, et al. Iron considerations for the athlete: a narrative review. Eur J Appl Physiol. 2019; 119 (7): 1463-78.

[25] Batchelor EK, Kapitsinou P, Pergola PE, Kovesdy CP, Jalal DI. Iron Deficiency in Chronic Kidney Disease: Updates on Pathophysiology, Diagnosis, and Treatment. J Am Soc Nephrol. 2020; 31 (3): 456-68.

[26] Begum S, Latunde-Dada GO. Anemia of Inflammation with An Emphasis on Chronic Kidney Disease. Nutrients. 2019; 11 (10).

[27] Collister D, Rigatto C, Tangri N. Anemia management in chronic kidney disease and dialysis: a narrative review. Curr Opin Nephrol Hypertens. 2017; 26 (3): 214-8.

[28] Murawska N, Fabisiak A, Fichna J. Anemia of Chronic Disease and Iron Deficiency Anemia in Inflammatory Bowel Diseases: Pathophysiology, Diagnosis, and Treatment. Inflamm Bowel Dis. 2016; 22 (5): 1198-208.

[29] Nielsen $\mathrm{OH}$, Soendergaard C, Vikner ME, Weiss G. Rational Management of Iron-Deficiency Anaemia in Inflammatory Bowel Disease. Nutrients. 2018; 10 (1).

[30] Girelli D, Marchi G, Camaschella C. Anemia in the Elderly. Hemasphere. 2018; 2 (3): e40.

[31] Lanier JB, Park JJ, Callahan RC. Anemia in Older Adults. Am Fam Physician. 2018; 98 (7): 437-42.

[32] García Erce JA, Altés A, López Rubio M, Remacha AF. Management of iron deficiency in various clinical conditions and the role of intravenous iron: Recommendations of the Spanish Erythropathology Group of the Spanish Society of Haematology and Haemotherapy. Revista clinica espanola. 2020; 220 (1): 31-42.

[33] Lopez A, Cacoub P, Macdougall IC, Peyrin-Biroulet L. Iron deficiency anaemia. Lancet. 2016; 387 (10021): 907-16.

[34] Danisi M FS. Terapia dell'anemia sideropenica: studio controllato ferritina versus ferroproteinsuccinilato. Riforma Med. 1987; 102: 457-9.

[35] Gordeuk VR, Brittenham GM, McLaren CE, Hughes MA, Keating LJ. Carbonyl iron therapy for iron deficiency anemia. Blood. 1986; 67 (3): 745-52.

[36] Cogo R. Comparison of efficacy and tolerability of iron proteinsuccinilate vs. a ferritin compound in iron-deficient patients. Boll Chim Farm. 1988; Suppl. Cli.

[37] DiSomma C MP, Spiga L, et al. Valutazione comparativa del trattamento con ferroproteinsuccinilato e ferritina. Riforma Medica. 1988; 103: 385-8.

[38] Ekenved G, Norrby A, Solvell L. Serum iron increase as a measure of iron absorption - studies on the correlation with 
total absorption. Scand J Haematol Suppl. 1976; 28: 31-49.

[39] DiGiacomo G DD, D'Antonio S, et al.. Loading Serum Iron Curve and Iron Absoption after the Administration of three different preparations. La Riv Medica Ital 1987; VI: 4-5. 1987.

[40] Pedrazzoli P, Scotti A, Farina D. Comparison trial of iron succinylprotein complex or iron gluconate complex in the treatment of iron deficiency anemia. Clin Ther. 1988; 10 (4): 414-20.

[41] Pogliani E SA, Acuto G. Clinical efficacy and tolerability of iron protein succinylate in comparison to slow release iron sulphate in sideropenic anemia. 1990.

[42] Liguori L. Iron protein succinylate in the treatment of iron deficiency: controlled, double-blind, multicenter clinical trial on over 1,000 patients. Int J Clin Pharmacol Ther Toxicol. 1993; 31 (3): 103-23.

[43] KDIGO Clinical Practice Guideline for Anemia in Chronic Kidney Disease. 2012. https://kdigo.org/wp-content/uploads/2016/10/KDIGO-2012Anemia-Guideline-English.pdf.

[44] NICE guideline [NG24]. Blood transfusion. https://www.nice.org.uk/guidance/ng24/chapter/Recommendat ions\#alternatives-to-blood-transfusion-for-patients-having-sur gery-2.

[45] Piccoli G. Assessment of the Biological Safety and the Subjective Tolerability of Iron Proteinsuccinylate in Patients with Chronic Renal Failure and Iron Deficiency. 1990.

[46] Gomez-Ramirez S, Bisbe E, Shander A, Spahn DR, Munoz M. Management of Perioperative Iron Deficiency Anemia. Acta Haematol. 2019; 142 (1): 21-9.

[47] Abeysiri S, Chau M, Richards T. Perioperative Anemia Management. Semin Thromb Hemost. 2020; 46 (1): 8-16.

[48] Kotze A, Harris A, Baker C, Iqbal T, Lavies N, Richards T, et al. British Committee for Standards in Haematology Guidelines on the Identification and Management of Pre-Operative Anaemia. Br J Haematol. 2015; 171 (3): 322-31.

[49] Kim YH, Chung HH, Kang SB, Kim SC, Kim YT. Safety and usefulness of intravenous iron sucrose in the management of preoperative anemia in patients with menorrhagia: a phase IV, open-label, prospective, randomized study. Acta Haematol. 2009; 121 (1): 37-41.

[50] Muñoz M, Acheson AG, Bisbe E, Butcher A, Gómez-Ramírez S, Khalafallah AA, et al. An international consensus statement on the management of postoperative anaemia after major surgical procedures. Anaesthesia. 2018; 73 (11): 1418-31.

[51] Ambrosini A. [The activity and tolerability of ferroproteinsuccinylate in the treatment of iron deficiency in surgery]. Bollettino chimico farmaceutico. 1988; 127 (3): $40 \mathrm{~s}-3 \mathrm{~s}$.

[52] Manfredi B, Finelli F. [A new therapeutic approach to iron deficiency]. La Clinica terapeutica. 1987; 123 (1): 25-39.

[53] Veneroni G CS, Tripodi S, et al. Studio clinico controllato in doppio cieco sull'efficacia terapeutica e sulla tollerabilità di un nuovo prodotto a base di ferro organico. Policlin Sez Med 1996; 103: 21-9.
[54] Guralnik JM, Eisenstaedt RS, Ferrucci L, Klein HG, Woodman RC. Prevalence of anemia in persons 65 years and older in the United States: evidence for a high rate of unexplained anemia. Blood. 2004; 104 (8): 2263-8.

[55] Patel KV. Epidemiology of anemia in older adults. Semin Hematol. 2008; 45 (4): 210-7.

[56] Girelli D, Nemeth E, Swinkels DW. Hepcidin in the diagnosis of iron disorders. Blood. 2016; 127 (23): 2809-13.

[57] Busti F, Campostrini N, Martinelli N, Girelli D. Iron deficiency in the elderly population, revisited in the hepcidin era. Front Pharmacol. 2014; 5: 83.

[58] Gruppo Italiano di Studio sulla Sideropenia nell'Anziano. La carenza mariziale nella popolazione anziana instituzionalizzata: indicatori precoci e trattamento farmacologico con ferroproteinsuccinilato. G Gerontol. 1992; 40 .

[59] Ravanbod M, Asadipooya K, Kalantarhormozi M, Nabipour I, Omrani GR. Treatment of iron-deficiency anemia in patients with subclinical hypothyroidism. The American journal of medicine. 2013 ; 126 (5): 420-4.

[60] Soliman AT, De Sanctis V, Yassin M, Wagdy M, Soliman N. Chronic anemia and thyroid function. Acta bio-medica: Atenei Parmensis. 2017; 88 (1): 119-27.

[61] Szczepanek-Parulska E, Hernik A, Ruchala M. Anemia in thyroid diseases. Polish archives of internal medicine. 2017; 127 (5): 352-60.

[62] Duntas LH, Krassas GE, Mantzou E, Koutras DA. Effectiveness of Combined Treatment with L-Thyroxine and Iron Proteinsuccinylate in Patients with Subclinical Hypothyroidism and Manifested Sideropenic Anemia. Nutritional Neuroscience. 2000; 3 (6): 407-14.

[63] Spencer BR. Iron Depletion in Adult and Teenage Blood Donors: Prevalence, Clinical Impact, and Options for Mitigation. Hematol Oncol Clin North Am. 2019; 33 (5): 781-96.

[64] Cable RG, Brambilla D, Glynn SA, Kleinman S, Mast AE, Spencer BR, et al. Effect of iron supplementation on iron stores and total body iron after whole blood donation. Transfusion. 2016; 56 (8): 2005-12.

[65] Landucci G, Frontespezi S. Treatment of iron deficiency conditions in blood donors: controlled study of iron sulphate versus iron protein succinylate. The Journal of international medical research. 1987; 15 (6): 379-82.

[66] Burden RJ, Morton K, Richards T, Whyte GP, Pedlar CR. Is iron treatment beneficial in, iron-deficient but non-anaemic (IDNA) endurance athletes? A systematic review and meta-analysis. British journal of sports medicine. 2015; 49 (21): 1389-97.

[67] Trojachanec Z. Sport Anemia and Sports Results.

[68] Cordova A, Mielgo-Ayuso J, Fernandez-Lazaro CI, Caballero-Garcia A, Roche E, Fernandez-Lazaro D. Effect of Iron Supplementation on the Modulation of Iron Metabolism, Muscle Damage Biomarkers and Cortisol in Professional Cyclists. Nutrients. 2019; 11 (3).

[69] DeLoughery TG. Safety of Oral and Intravenous Iron. Acta Haematol. 2019; 142 (1): 8-12. 
[70] Bayraktar UD, Bayraktar S. Treatment of iron deficiency anemia associated with gastrointestinal tract diseases. World J Gastroenterol. 2010; 16 (22): 2720-5.

[71] Cremonesi P, Caramazza I. Chemical and biological characterization of iron-protein succinylate (ITF 282). Int $\mathrm{J}$ Clin Pharmacol Ther Toxicol. 1993; 31 (1): 40-51.

[72] Raja KB, Jafri SE, Dickson D, Acebron A, Cremonesi P, Fossati G, et al. Involvement of iron (ferric) reduction in the iron absorption mechanism of a trivalent iron-protein complex (iron protein succinylate). Pharmacol Toxicol. 2000; 87 (3): 108-15.

[73] Cogo R, De Luca P, Mastrantoni M. Evaluation of the siderohaemic curve after loading administration of iron--protein--succinylate to gastrectomized subjects: a controlled study. The Journal of international medical research. 1990; 18 (3): 225-7.

[74] Danisi M, Guerresi E, Landucci G, Gori G, Ceccarelli G. Serum iron concentrations following administration of two different iron preparations. J Int Med Res. 1987; 15 (6): 374-8.
[75] Cogo R. [Comparison of the efficacy and tolerability of ferroproteinsuccinylate and ferritin preparations in iron deficiency in general medicine]. Bollettino chimico farmaceutico. 1988; 127 (3): 25s-9s.

[76] Gafter-Gvili A, Schechter A, Rozen-Zvi B. Iron Deficiency Anemia in Chronic Kidney Disease. Acta Haematol. 2019; 142 (1): 44-50.

[77] Gómez Ramírez S, Remacha Sevilla ÁF, Muñoz Gómez M. Anaemia in the elderly. Medicina Clínica (English Edition). 2017; 149 (11): 496-503.

[78] Kopcke W, Sauerland MC. Meta-analysis of efficacy and tolerability data on iron proteinsuccinylate in patients with iron deficiency anemia of different severity. Arzneimittelforschung. 1995; 45 (11): 1211-6. 